\title{
DISGONTINUOUS FLOW, ICE TEXTURE, AND DIRT GONTENT IN THE BASAL LAYERS OF THE DEVON ISLAND ICE CAP
}

\author{
By R. M. Koerner and D. A. Fisher \\ (Polar Continental Shelf Project, Department of Energy, Mines and Resources, Ottawa, \\ Ontario $\mathrm{K}_{\mathrm{IA}}$ oE 4 , Canada)
}

Abstract. Surface-to-bedrock cores obtained with a CRREL thermal drill were taken in 1972 and 1973 from the top of the Devon Island ice cap. There are very pronounced variations in oxygen isotope, microparticle concentration, and ice texture in the lowermost $5 \mathrm{~m}$ of the core. There is a section of isotopically cold, very fine bubbly ice with high micro-particle concentrations between 2.6 and $4.4 \mathrm{~m}$ above the bed, considered to represent the Last Ice Age. There is coarse, isotopically warm, clean ice above and below this. For $1.2 \mathrm{~m}$ above the bed, the ice is finer again with high micro-particle concentrations but it shows very low bubble concentration and is isotopically the warmest in the core. While the broad variations are common to both cores, in detail there are significant variations despite the fact that the cores were taken only $27 \mathrm{~m}$ apart. The variations, when analysed statistically, show that at least $25-30 \%$ of the originally continuous profile is missing from each core. Faulting within the near-bedrock ice may be responsible for some of the effect but bubble fabric also gives evidence for irregular non-laminar flow. Because of the strong relationship between crystal size and micro-particle concentrations in the Devon Island cores, it is suggested that the fine-grained nature of dirty layers in the Antarctic and Greenland ice sheets is due to the effect of the dirt inclusions and not of shearing. Steep isotopic gradients in the Devon Island cores are shown to be evidence for possible shearing, which does not effect any change in the crystal texture. Clear ice near the bed is considered a tectonic feature, but the lack of effect on its bed by the ice cap confirms the non-erosional nature of an ice cap frozen to its bed.

In terms of paleoclimatic history, it means that, because of bedrock effects, ice caps of intermediate depth (i.e. $<400 \mathrm{~m}$ ) can give continuous information only over the last approximate 5 ooo years. Between 5 ooo and 10 ооо B.P. the time series becomes slightly discontinuous and beyond 10 000 B.P. so discontinuous as to allow only broad climatic inferences to be drawn.

RÉSUMÉ. Ecoulements discontinus, texture de la glace et teneur en débris dans les niveaux de base de la calotte glaciaire de l'île Devon. On a prélevé avec une sonde thermique CRREL des carottes continues surface-bedrock en 1972 et 1973 depuis le sommet de la calotte glaciaire de l'Île Devon. Il y a des variations très prononcées en isotopes de l'oxygène, en concentration en micro-particules et en texture de la glace dans les cinq derniers mètres au bas de la carotte. Il y a une section d'une glace isotopiquement froide, très finement bulleuse, riche en micro-particules entre 2,6 et 4,4 $\mathrm{m}$ au dessus du lit, que l'on considère comme représentant le Dernier Age Glaciaire. Au dessus et en dessous, on trouve une glace propre, à gros grains, isotopiquement chaude. Sur $1,2 \mathrm{~m}$ au dessus du lit, la glace est de nouveau à grains plus fins avec une forte concentration en bulles et est, isotopiquement la glace la plus chaude de la carotte. Bien que de fortes variations soient courantes dans les deux carottes, il y a dans les détails des variations significatives entre les deux carottes en dépit du fait qu'elles ont été prélevées à seulement $27 \mathrm{~m}$ l'une de l'autre. Les variations ont été analysées statistiquement, elles montrent qu'au moins 25 à $30 \%$ du profil continu originel manque dans chaque carotte. Des défauts dans la glace voisine du bedrock peuvent être responsables de certains de ces effets mais la production de bulles montre aussi des preuves d'un écoulement irrégulier non laminaire. En raison de l'étroite relation entre la taille des cristaux et la concentration en microparticules dans les carottes de l'île Devon, on suggère que la structure à grains fins des niveaux salés dans les Calottes Antarctique et Groënlandaise est due à l'effet des inclusions d'impuretés et non au cisaillement. On montre que de forts gradients isotopiques dans les échantillons de l'Île Devon sont des signes d'un possible cisaillement, qui n'affecte en rien la texture cristalline. La glace claire près du lit est considérée comme un caractère tectonique mais l'absence d'action de la calotte sur son lit confirme la nature non érodante d'une calotte de glace froide sur son lit.

En terme d'histoire des paléoclimats, ceci signifie que, à cause des effets de lit, les calottes de glace d'épaisseur intermédiaire (c'est-à-dire inférieure à $400 \mathrm{~m}$ ) ne peuvent donner d'informations continues que sur environ les 5000 dernières années. Entre 5 ooo et ro ooo ans avant nos jours, la série temporelle devient peu à peu discontinue et au delà de ro 000 ans si discontinue qu'elle ne permet plus que des conclusions à très grands traits sur les climats.

Zusammenfassung. Diskontinuierliches Fliessen, Eis-Textur und Schmutzgehalt in den Schichten am Untergrund der Devon Island-Eiskappe. Am Scheitel der Devon Island-Eiskappe wurden 1972 und 1973 mit einem thermischen CRREL-Bohrer Kerne von der Oberfläche bis zum Felsbett gewonnen. In den 5 untersten Metern des Kernes treten sehr deutliche Schwankungen der Sauerstoff-Isotope, der Konzentration an Mikropartikeln und der Eistextur auf. Zwischen 2,6 und 4,4 $\mathrm{m}$ über dem Bett liegt eine Zone isotopisch kalten, sehr feinen, blasenreichen Eises mit hoher Konzentration an Mikropartikeln, die als Repräsentant der letzten Eiszeit anzusehen ist. Darüber und darunter findet sich grobes, isotopisch warmes, sauberes Eis. Ab I,2 $\mathrm{m}$ über dem Bett ist das Eis noch feiner mit hoher Konzentration an Mikropartikeln, aber es enthält nur wenige Blasen und ist das isotopisch wärmste des ganzen Kernes. Während die grösseren Schwankungen beiden Kernen gemeinsam sind, weisen sie im Detail doch signifikante Unterschiede auf, obwohl sie nur $27 \mathrm{~m}$ 
auseinander liegen. Analysiert man die Schwankungen statistisch, so findet man, dass zumindest $25-30 \%$ des ursprünglich kontinuierlichen Profils in beiden Kernen fehlen. Faltungen im untergrundsnahen Eis mögen teilweise für diesen Effekt verantwortlich sein, aber auch das Blasengefüge gibt Hinweise auf unregelmässiges, nicht-laminares Fliessen. Im Hinblick auf die strenge Beziehung zwischen Kristallgrösse und Konzentration an Mikropartikeln in den Kernen von Devon Island wird angenommen, dass die feinkörnige Natur von Schmutzschichten in den Eisschilden Grönlands und der Antarktis eine Folge der Schmutzeinschlüsse und nicht der Scherung ist. Steile isotopengradienten in den Devon Island-Kernen können als Beweis für mögliche Scherung gelten, die jedoch keine Änderung in der Kristalltextur bewirkt. Klares Eis nahe am Untergrund wird als tektonische Erscheinung betrachtet, doch bestätigt der Mangel an Wirkungen der Eiskappe auf ihr Bett den nicht-erosiven Charakter einer angefrorenen Eiskappe.

Hinsichtlich der paläoklimatischen Vorgeschichte lässt sich feststellen, dass Eiskappen mittlerer Dicke (d.h. $400 \mathrm{~m}$ ) infolge von Untergrundseffekten nur über etwa 5000 Jahre kontinuierliche Informationen liefern können. Zwischen 5000 und 10 ooo Jahren vor der Gegenwart wird die Zeitreihe leicht diskontinuierlich und früher als Io ooo Jahre zurück so unregelmässig, dass nur allgemeine klimatische Schlüsse gezogen werden können.

\section{INTRODUGTION}

The purpose of this paper is to illustrate the perturbations to ice flow produced in the basal layers of an ice cap by the underlying bedrock. To do this, micro-particle, crystal size, and $\delta^{18} \mathrm{O} /{ }^{16} \mathrm{O}$ ratios in two cores, drilled $27 \mathrm{~m}$ apart in 1972 and 1973 close to the same flow line $900 \mathrm{~m}$ north of the ice divide at $\mathrm{I} 800 \mathrm{~m}$ a.s.l. on the Devon Island ice cap, are compared. We also discuss changing ice texture in the basal layers of the Devon Island ice cap, which appears to be representative of an ice cap that has been frozen to its bed throughout its history. The bore holes are $298.9 \mathrm{~m}\left(\mathrm{D}_{72}\right)$ and $299.4 \mathrm{~m}$ (D73) deep. The annual accumulation at the bore-hole sites is $22 \mathrm{~g} \mathrm{~cm}^{-2}$, the temperature at $12 \mathrm{~m}$ depth in the firn is $-23^{\circ} \mathrm{C}$, and the area is in the percolation zone of Benson's (I96I) classification.

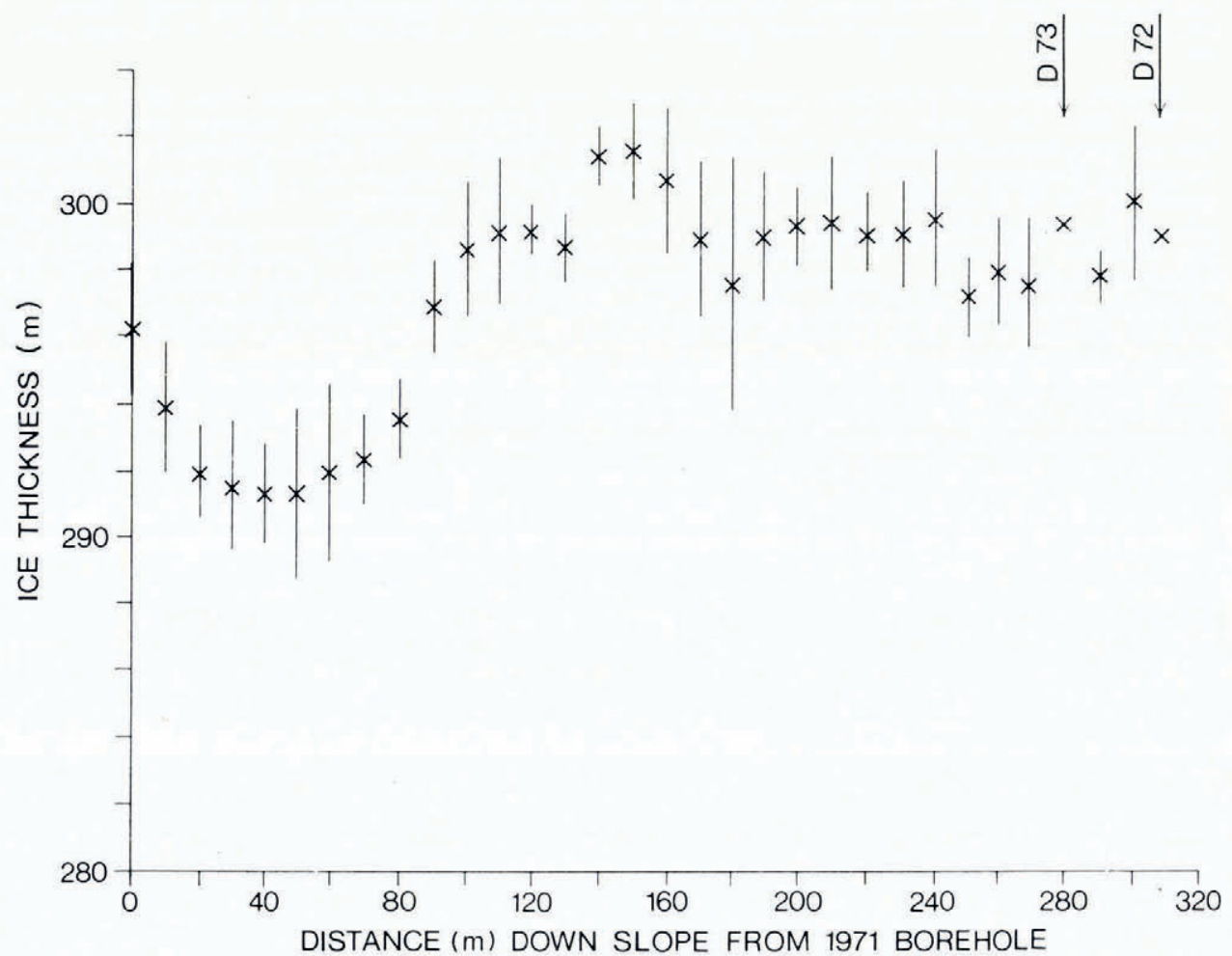

Fig. . I. Ice-thickness profile up the flow line from the Devon Island ice-cap cores. As the surface elevations change smoothly by only $3^{8} \mathrm{~m}$, this profile very closely approximates the bedrock profile. 
The bed conditions along the flow line are shown in Figure I (personal communication from C. S. M. Doake). The profile is also fairly typical of the north slope of the ice-cap crest in the vicinity of the drill site (Paterson and Koerner, 1974).

\section{General core properties (Table I)}

As this paper is chiefly a consideration of the glacier/bed relationships revealed by a study of cores $\mathrm{D}_{72}$ and $\mathrm{D}_{73}$, the textural and fabric variations of the main body of the ice will only be reviewed briefly.

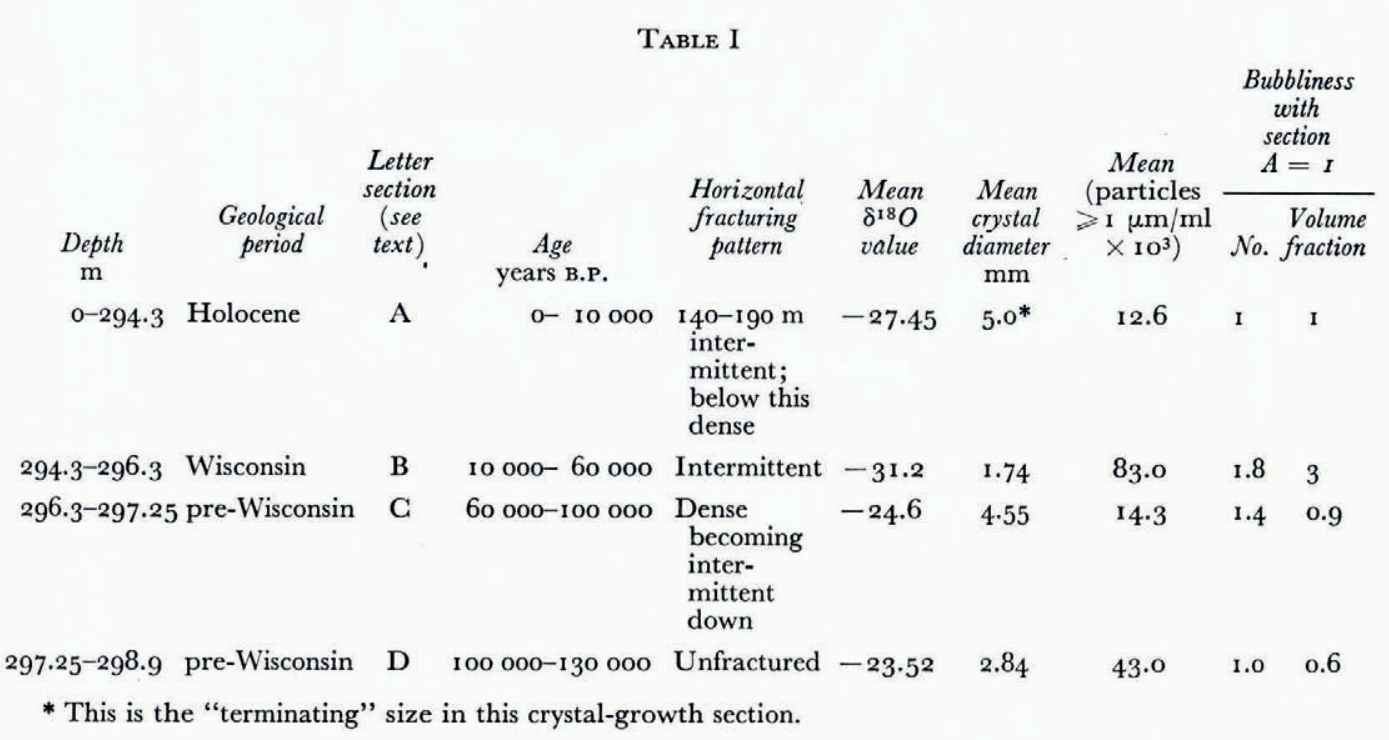

The two cores $\left(\mathrm{D}_{72}\right.$ and $\mathrm{D}_{73}$ ) were recovered without core loss with a CRREL-built thermal drill. Vertical fractures occurred in the ice cores between depths of 80 and $190 \mathrm{~m}$. Horizontal micro-fractures began intermittently at $140 \mathrm{~m}$ and by $190 \mathrm{~m}$ depth occurred throughout each core. Intermittent horizontal fracturing re-appeared at $294 \mathrm{~m}$ and, for the last I $\mathrm{m}$ above the bed, the ice was unfractured. The vertical fractures were caused by the effect of both the core catchers and a small scriber towards the base of the drill on the core as it was drawn from the drill barrel. The horizontal fracturing is probably the effect of thermal shock on ice which has developed a preferred orientation of its $c$-axes, although we would point out that the plane of fracturing is about $10-20^{\circ}$ different from the modal basalplane direction of the crystals. The fractures are tight enough to prevent any measurable contamination of the chemical and isotopic composition of the ice we discuss. The ice-bedrock contact is sharp, i.e. there is no basal moraine in the ice. However, the lowermost metre of each ice core contains silt-sized particles.

Crystal diameters (measured in the vertical direction) in the ice increase from $2.6 \mathrm{~mm}$ at $75 \mathrm{~m}$ depth to $5.0 \mathrm{~mm}$ at $180 \mathrm{~m}$ depth (a growth rate of about $4 \times 10^{-3} \mathrm{~mm}^{-1} \mathrm{ear}^{-1}$, about I.5 times the growth-rate at Byrd Station (Gow and Williamson, 1976)). Below that the growth-rate is very slight. However, there are crystal-size variations in the basal layers which have been used for comparing the two cores (Fig. 2). We will show that these size variations are directly related to varying particulate concentrations where crystal growth is inhibited by micro-particle inclusions. 


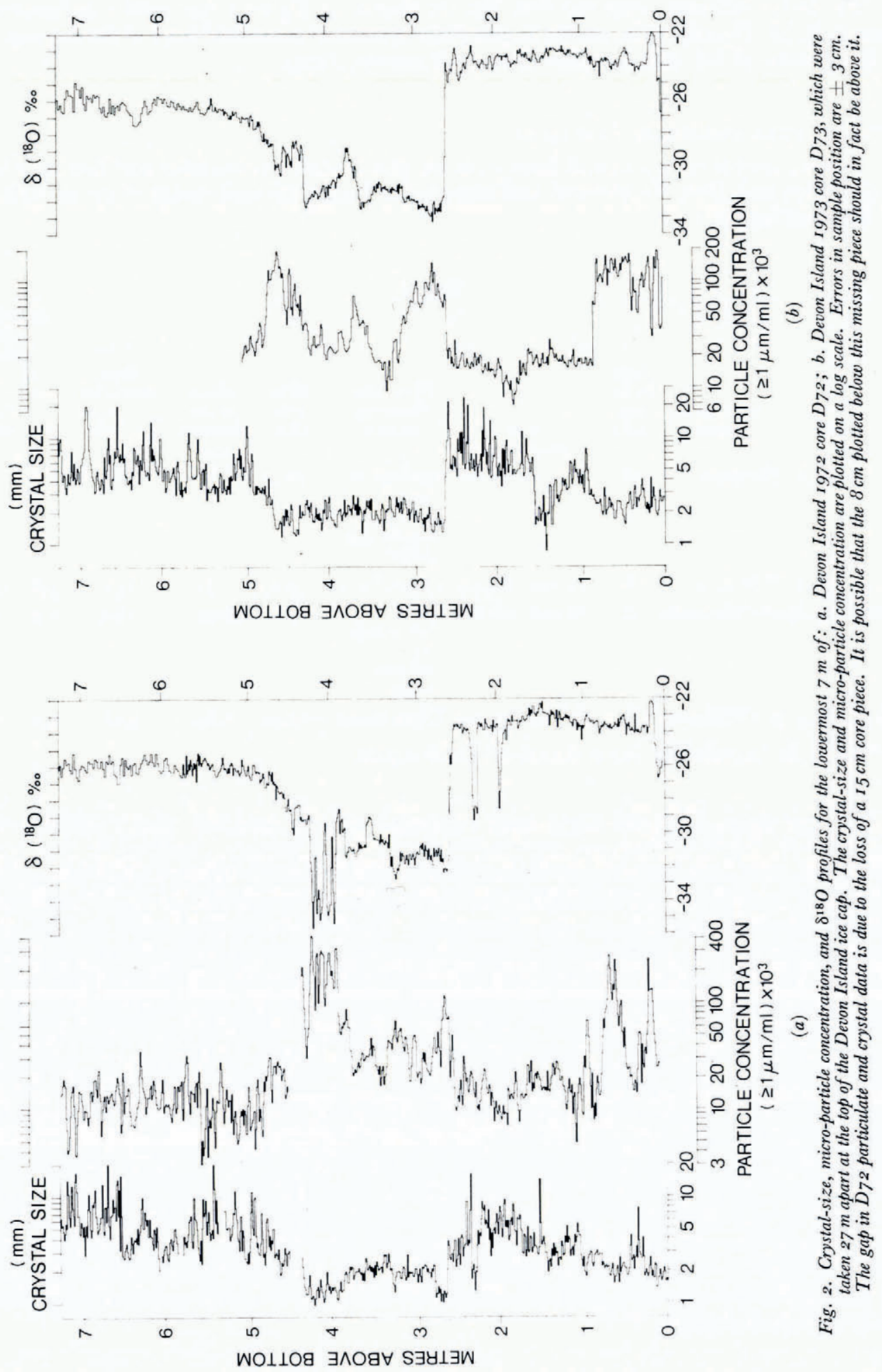


The $c$-axes of the crystals begin to array in preferred orientations between 100 and $150 \mathrm{~m}$ depths and by $200 \mathrm{~m}$ depth show a strong single-pole orientation $20^{\circ}$ from the vertical. There is no significant alteration in the strength or position of the single-pole concentration below this.

On the basis of ice texture, dirt content, and $\delta$ values, the core may be divided into four sections as detailed in Table I. Sections A and C are texturally similar. Section B has been identified as Wisconsin (Paterson and others, 1977) and section D has been thought to represent ice formed in the superimposed ice zone on the ice cap when it was considerably smaller; we show later that this may not be the case.

There are no major variations in the concentration of micro-particles $\geqslant_{1} \mu \mathrm{m}$ diameter (which lie in the range of $8 \times \mathrm{IO}^{3}$ to $16 \times \mathrm{IO}^{3} \mathrm{ml}^{-1}$ ) for the uppermost $294 \mathrm{~m}$ of each core. Below that, where we enter ice of Wisconsin (B) and pre-Wisconsin age ( $C$ and $D)$ (Paterson and others, 1977), there are major variations. As the micro-particle profile can only be altered by non-laminar flow of the ice rather than by molecular diffusion $\left(\delta^{18} \mathrm{O}\right)$ or grainboundary migration (crystals), it serves as an additional datum signature for comparing $D_{72}$ and $D_{73}$ in terms of ice dynamics. Micro-particle concentrations $(p)$ in numbers of particles $\geqslant \mathrm{I} \mu \mathrm{m}$ diameter have been correlated against crystal size $(I)$ in $\mathrm{mm}$ diameter in $200 \mathrm{~mm}$ sections from $\mathrm{D}_{72}$. There is a strong relationship where $r=0.7$ (significant at the $<0.5$ level) and can be taken as a power law. Where $2 \mathrm{~mm}<I<4.5 \mathrm{~mm}$ the relationship is:

$$
I / I^{\star}=24\left(p / p^{\star}\right)^{-0 \cdot 78}
$$

and for $0<I<2.0 \mathrm{~mm}$ the relationship is:

$$
I / I^{\star}=\mathrm{I} .49\left(p / p^{\star}\right)^{-0.2},
$$

where $I^{\star}$ and $p^{\star}$ are the smallest crystal diameters and lowest particle concentrations, respectively, viz. I. $0 \mathrm{~mm}$ and $8 \times 1 \mathrm{IO}^{6}$ particles $\mathrm{l}^{-1}$. For $p<\mathrm{I} 4 \times \mathrm{IO}^{3}$ particles $\mathrm{ml}^{-1}$, the relationship breaks down which is the case for the upper $290 \mathrm{~m}$ of the core.

\section{Previous WORK}

Fisher (unpublished [a]) and Paterson and others (1977), in a study of the $\delta^{18} \mathrm{O}$ profiles in $\mathrm{D}_{72}$ and $\mathrm{D}_{73}$, concluded that $25-30 \%$ of each core record was missing from the lowermost $6 \mathrm{~m}$ with an additional $6-9 \%$ missing from both cores. Using a sliding correlation technique on the $\delta$ profiles, Fisher (unpublished [a]) identified sections of each core which correlated highly enough to assume them to be identical temporally. Fisher (unpublished [a]) then reconstructed a Devon Island ice-cap $\delta$ record using both cores and ignoring the possible $6-9 \%$ combined loss; a similar reconstruction is in Paterson and others (1977). Fisher (unpublished $[\mathrm{b}]$ ), using the same correlation technique for the crystal-size data (Fig. I), confirmed his $\delta$ profile reconstruction in most, but not all, cases. In his original core comparison, he also concluded that the two profiles are discontinuous for $13 \mathrm{~m}$ above the bed; above that the records are comparable.

Paterson and others (1977) concluded that the missing parts were due to:

i. Variations in the vertical strain-rate over short horizontal distances.

ii. Faulting.

iii. Highly compressed sections where the isotope variations have been smoothed out by diffusion.

We will now expand on this aspect of our work.

\section{Results}

The particulate and crystal-size profiles for $\mathrm{D}_{72}$ and $\mathrm{D}_{73}$ are shown together with that for $\delta^{18} \mathrm{O}$ in Figure 2. The particle profiles emphasize that, although core recovery was $100 \%$, the two records are discontinuous in the basal layers. This is in the sense that, although all 
the various sections may be present, some are in an unmeasurably attenuated form. For example, section B with a generally very high micro-particle concentration is $10 \%$ longer in $\mathrm{D}_{73}$ than in $\mathrm{D}_{72}$. Within this same section the increment of highest micro-particle concentrations in either core occurs in $\mathrm{D}_{72}$ at the top of section B; it is absent from $\mathrm{D}_{73}$. The highest micro-particle concentration in $\mathrm{D}_{73}$ occurs in ice with a different $\delta$ value to the high microparticle concentration section of $\mathrm{D}_{72}$ so that it is missing from $\mathrm{D}_{72}$. The dirty sections in the lowermost $\mathrm{I} \mathrm{m}$ of each core also differ substantially from each other. However, isolated dirt pockets in this section may have introduced random peaks into either profile. Thus, despite the closeness of the two cores, and the fact that they lie very close to but not exactly on the same flow line, a variable vertical strain-rate has been introduced by flow over $900 \mathrm{~m}$ of fairly smooth bed (Fig. I).

It is not possible to quantify this. On the one hand, the four principal sections are clear in both $\mathrm{D}_{72}$ and $\mathrm{D}_{73}$, which means that the non-laminar nature of flow is not sufficient to obliterate whole I $\mathrm{m}$ sections. On the other hand, the Wisconsin section (B) in $\mathrm{D}_{73}$ is $500 \mathrm{~mm}$ longer than in $\mathrm{D}_{72}$; i.e. $500 \mathrm{~mm}$ are "missing" from this section of $\mathrm{D}_{72}$.

\section{FLOW PROCESSES}

The first process that could explain the variable vertical strain-rate is the thinning and thickening of layers as the ice flows over the uneven bed. Figure 3 shows the bubble structure of an ice vertical section from $290.7 \mathrm{~m}$ depth in $\mathrm{D}_{72}$. The section was cut along the long axis of bubble stretching, which we assume approximates the flow line. However, we do not know the azimuth of the section so the flow direction also remains unknown. Therefore, we cannot say whether "bubble flow lines" show evidence for the thickening or thinning of a layer. Such examples are in fact not common and the illustrated one is the best example found in about $10 \mathrm{~m}$ of sections.
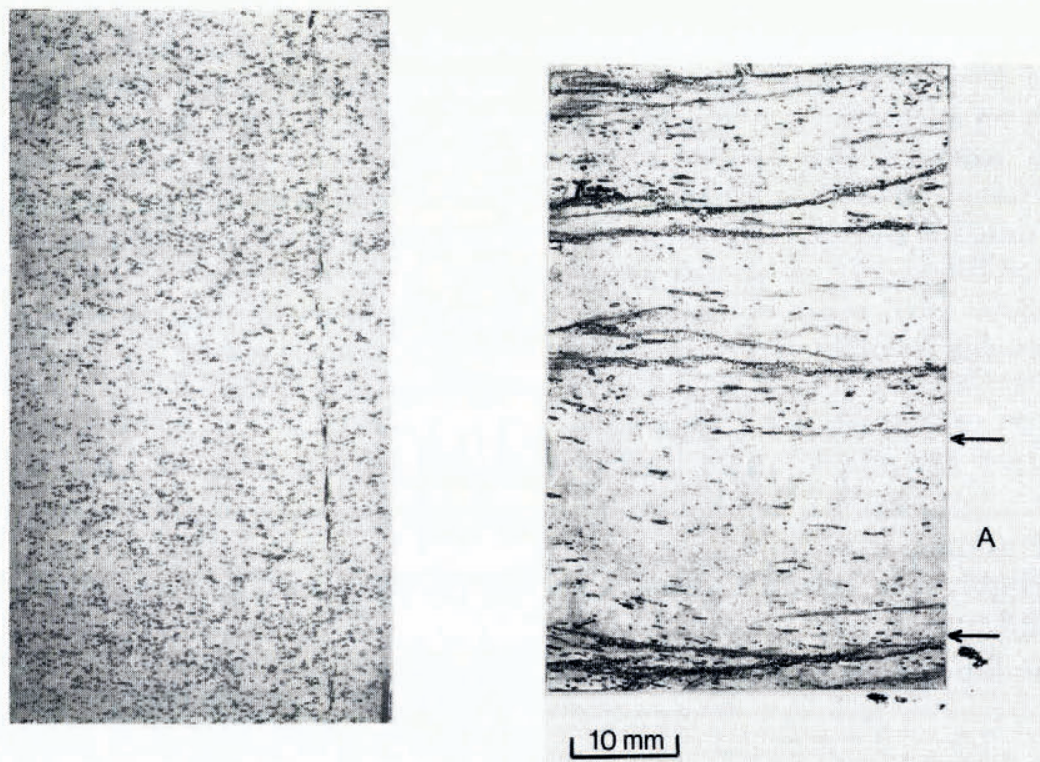

Fig. 3. Bubble textures and fractures in core $D_{72}$ at $3.5 \mathrm{~m}$ above the bed (left-hand photograph) and $8.0 \mathrm{~m}$ above the bed. The $3.5 \mathrm{~m}$ above-bed picture shows the dense bubble texture of "cold" Wisconsinan ice. The $8.0 \mathrm{~m}$ above-bed picture shows the fracturing typical of most of the lower half of the $298.9 \mathrm{~m}$ core in addition to bubble stretching and variable layer thickness (section A) at this depth. The sections are shown in their true orientation. 
A second process, which causes a variable vertical strain-rate to exist in the basal layers, is due to the effect on the flow dynamics of the different properties of the fine- and coarsegrained ice. Paterson (1977) found tertiary creep-rates four times those of the ice immediately above and below the $2.6-4.25 \mathrm{~m}$ fine-grained section. Very recent measurements in a bore hole on Agassiz Ice Cap in northern Ellesmere Island confirm Paterson's (I977) work. In this case, the bore hole was filled with diesel oil a few days after it was drilled. Caliper measurements made I year apart show closure-rates in ice texturally the same as section B in $\mathrm{D}_{72}$ and D73 much higher than those of the ice above and below it for the I year. Paterson (1977) attributed the high creep-rate in the $\mathrm{D}_{72}$ hole to the softer nature of the fine-grained ice and its greater ability to recrystallize. He cited as supportive evidence Hooke's (1973) findings on the Barnes Ice Cap where a bore-hole tilt experiment found that for a given stress, the shear strain of Wisconsin (type B) ice of $\mathrm{D}_{72}$ and $\mathrm{D}_{73}$ was double that of the ice above and below it. The different flow properties of this section mean that it will also have a vertical strain-rate different from the rest of the ice.

The fine-grained sections ( $\mathrm{B}$ and part of $\mathrm{D}$ ) also contain crystal domains which we term stringers (Fig. 4). These domains consist of crystals generally aligned $10-20^{\circ}$ from the vertical. They are up to $600 \mathrm{~mm}$ long and 3-10 $\mathrm{mm}$ wide. The crystals show a common $c$-axis orientation about $5^{-6^{\circ}}$ different from the surrounding ice. What relationship they bear to the flow dynamics is not known, although they may be related to some faulting mechanism which would again effect discontinuities in the basal $\mathrm{r} 3 \mathrm{~m}$ section.

One flow mechanism we feel we can discount is that of dike-sill formation (Hughes, 1977). Hughes suggested that "cold spikes" (very negative $\delta$ ice) in the Byrd Station and Camp Century cores are due to convective flow, which, by a dike-sill mechanism, injects ice from regions close to the bed (and therefore formed originally higher up the flow line at greater (colder) elevations) up and into warmer (less negative $\delta$ ) ice. Our cores were taken very close to the top of the flow line and our very cold (more negative $\delta$ ) ice sits on top of the

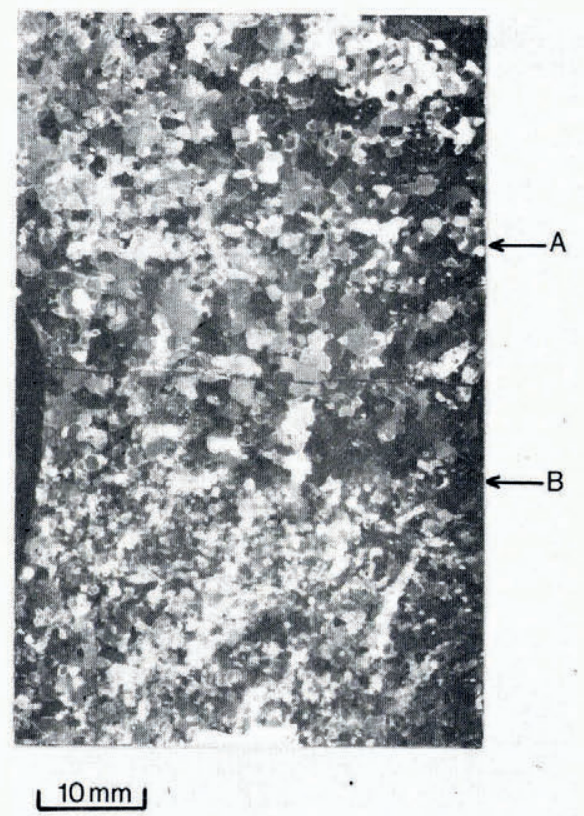

Fig. 4. Ice crystal-size variations $4 \cdot 1-4: 2 \mathrm{~m}$ aboie the bed. Note the fine-grained laver at $A$ and the fine-grained section below B. Stringers (see text) appear in the middle of the photograph and again on the right-hand side below B. The slide is shown in its true orientation. 
warmest (less negative $\delta$ ) ice in the core. Therefore, the dike-sill mechanism cannot apply here. Yet we still have "cold spikes" and, furthermore, they have similar micro-particle and chemistry signatures to those at similar age levels in the Camp Century core (paper in preparation by R. M. Koerner). We suggest the same mechanism cannot be causing the "cold spikes" in the Camp Century core either.

A third process by which layers may be excessively attenuated is shearing. On the basis of the fine-grained texture of several dirt layers, which have a slight difference in the strength of the single-pole $c$-axis fabric to that of the enclosing ice, Gow and Williamson (1976) considered the layers to be narrow shear zones. They did not present a statistical analysis to determine whether the single-pole fabric of these dirt layers is significantly different from that of the surrounding ice but qualitatively they felt the dirt-layer fabric is unique. Our work illustrates the strong relationship between crystal size and particle inclusions, and we suggest the finegrained nature of these layers in the Byrd Station core may be due to the dirt inclusions rather than to a shearing mechanism. There is ample evidence to show that dirt inclusions affect the softness and strain-rate of ice (summarized by Gell (unpublished)). In our case, the dirt inclusions have effected a more plastic layer, not a shear zone (see above). We, therefore, question whether the Byrd Station dirt layers are indeed shear zones; instead they may be narrow zones of slightly more plastic ice. Gow and Williamson (1976) in fact admitted to the possibility that, in the lowermost of these volcanic layers (at $2000 \mathrm{~m}$ ) the volcanic particles may have "anchored" the crystal boundaries.

We find very fine-grained layers in section B of $\mathrm{D}_{72}$ (Fig. 4) which correlate with higher dirt concentrations and more negative $\delta$ values at the same level. However, there is no evidence to cite them as shear zones. Conversely, we may have shear planes in the Devon Island ice-cap basal layers without crystallographic evidence for it. Fisher (unpublished [a]) has drawn attention to the very steep nature of the $\delta$ gradients in $\mathrm{D}_{72}$ at 2.3 and $2.6 \mathrm{~m}$ above the bed. He has noted that most of the more evident $\delta$ discontinuities are associated with sharp $\delta$ gradients. He calculated the age of the steep $2.6 \mathrm{~m} \delta$ gradient by using Johnsen's diffusion model and concluded that the gradient as measured could be no older than I ooo

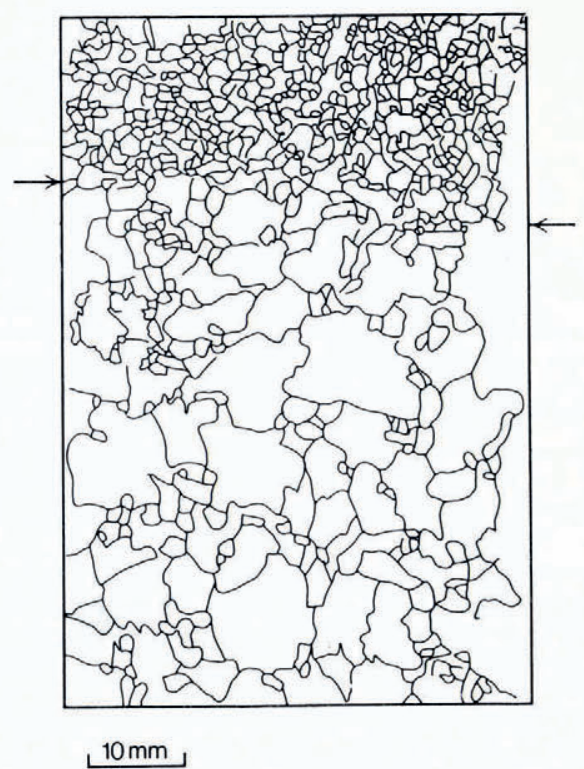

Fig. 5. Tracing of an ice thin section showing the discontinuity between fine ice of Wisconsinan age (above arrows) and coarse ice of pre-Wisconsinan age in $D_{72}$. The discontinuity is $2.6 \mathrm{~m}$ above the bed. 
years in ice which is about 60 ooo years old. Now, the magnitude of the $\delta$ step is reduced by the effect of $10 \mathrm{~mm}$ sampling, which, while giving a resolution no better than the $10 \mathrm{~mm}$ sample thickness, also cuts across non-horizontal bedding planes. If the $\delta$ step is as sharp as that visible in the crystal-size change (Fig. 5), and there is every reason to believe it is, then the step is calculated to be of such recent origin that it must be a feature which is continually forming. As such, it may represent a shear plane continually bringing new sections of our two ice types B and C (Table I) together. Steep $\delta$ (or dirt) gradients in the core elsewhere may similarly be shear planes. Examples of this can be seen at the bottom of the very negative $\delta$ section at about $4 \mathrm{~m}$ above bed in $\mathrm{D}_{72}$ and again at the bottom of the narrow very negative $\delta$ section at 2. $\mathrm{m}$ above the bed in $\mathrm{D}_{72}$ (Fig. 2).

\section{Dirt content in the Basal LAyers}

We will first establish that our drill holes extend to bedrock rather than to a debris-ridden layer within the ice. First, the $\delta^{18} \mathrm{O}$ profiles (Fig. 2) show that the cores penetrated to ice thought to be older than that shown in the published Camp Century cores which excluded the debris-ridden layers (Dansgaard and others, I969). Thus our basal ice is probably of comparable age to at least some of the debris-ridden Camp Century ice. Secondly, from a consideration of the present basal temperature $\left(-18^{\circ} \mathrm{C}\right)$, present thickness $(300 \mathrm{~m})$, and calculated maximum thickness of $450 \mathrm{~m}$ in the past (Paterson and others, 1977), it is most unlikely that the base of the ice cap has ever been at the pressure-melting point. Thus, a clear-cut ice/bed interface is consistent with the temperature history of the ice cap. Thirdly, a similar four-step sequence of ice textures has been found in the basal layers of the core taken with a thermal drill from the Agassiz Ice Cap in 1977 in northern Ellesmere Island. In the

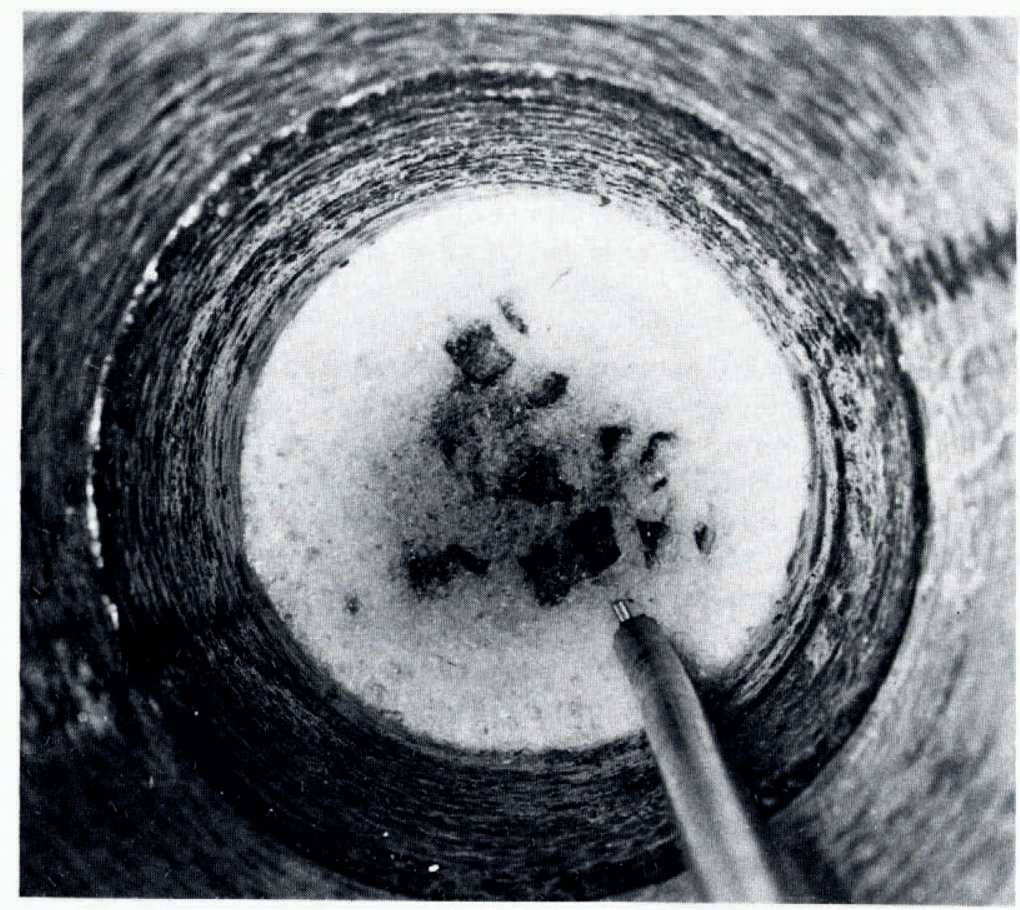

Fig. 6. Photograph taken of bedrock at the base of a $337 \mathrm{~m}$ hole drilled on the Agassiz Ice Cap, northern Ellesmere Island in May 1977. The bore-hole diameter is $16 \mathrm{~cm}$. 
Ellesmere Island drilling we were able to extract the last piece of ice with rock fragments attached to it by taking the drill head off to expose the core catchers at the end of the thermal drill barrel. A photograph of the bed (Fig. 6) shows that the bedrock is composed of loose, angular rock fragments. Even if we assume that what appeared to be ice chippings broken from the upper layers of firn above $60 \mathrm{~m}$ depth, as the drill and camera were lowered down the hole, are in situ ice, which is very unlikely, we find a rock percentage of $3 \mathrm{I}$. This is unrealistically high to assume as a debris layer in the ice when compared to the $15.7 \%$ maximum at Byrd Station (Gow and others, 1979), the $0.42 \%$ at Camp Century (Herron and Langway, 1979), and the $3.8 \%$ in the upper dispersed layer in Matanuska Glacier (Lawson, I979), particularly when we consider our bore-hole site is only I km from the top of the flow line. Thus we believe we penetrated to bedrock on Ellesmere Island. Because of the very close similarity between the basal layers of $\mathrm{D}_{72}$ and $\mathrm{D}_{73}$ on the one hand and the Ellesmere Island core on the other, we feel we also penetrated to bedrock in the Devon Island ice cores. Final support for this conclusion comes from a rock fragment brought up on the heating annulus of the drill at the base of $\mathrm{D}_{72}$ and sharp indentations made on the annulus by free-dropping the drill for $\mathrm{I} m$ back on to the bed in $\mathrm{D}_{73}$.

The basal layers of the Devon Island ice-cap cores are of particular interest in that the ice has almost certainly been frozen to its bed throughout its history. This is in contrast to the Byrd Station area of West Antarctica, where the ice is presently at pressure-melting point at the bed (Gow and others, 1979), and the Camp Century area of Greenland, where the ice sheet has been at the pressure-melting point at its bed at some time during its history (Herron and Langway, 1979). Thus, there is also a contrast in the debris content of the basal layers of the Byrd Station and Camp Century areas on the one hand and the Devon Island (and Agassiz) ice caps on the other. The Byrd Station and Camp Century debris are considered to have been frozen-in (Gow and others, 1979; Herron and Langway, 1979). Although the Devon Island ice-cap basal layers (sections B and D, Table I) are dirtier than the rest of the ice, we do not consider this dirt to have been frozen or even sheared into the ice from the bed.

In section B there is a very high micro-particle concentration level, but the particles are of a generally smaller-sized fraction than in the Holocene section above it and the older ice below it. This gives us reason to believe the dust is of wind-blown origin like the microparticles throughout the entire length of both $\mathrm{D}_{72}$ and $\mathrm{D}_{73}$. The finer nature of the dust is due to its longer travel path over the much larger ice caps of the Arctic islands and North American continent at the time. There is published evidence for high micro-particle concentrations in ice of equivalent age but at quite different distances from the bed in West Antarctica (Byrd Station), East Antarctica (Vostok), Greenland (Camp Century), and the Barnes Ice Cap of Arctic Canada. Thompson and others (1975) found high micro-particle concentrations in ice of Wisconsinan age in the Byrd Station core, where Gow and Williamson (1976) found a sudden transition to fine ice. Ragone and others (1972) and Cragin and others ([ ${ }^{\mathrm{C}}{ }_{1977]}$ ) all found high levels of various elements in ice of Wisconsinan age in the Camp Century core. These elements are almost certainly representative of fine micro-particle concentrations. Recently, Hammer and others (1978) have in fact found high micro-particle concentrations in the same ice. In the Vostok core (Barkov, 1973), finer-grained ice appears below a depth of about $300 \mathrm{~m}$, which, if we consider an annual accumulation of $3.0 \mathrm{~g} \mathrm{~cm}^{2}$ (Kotlyakov, I96r), means it is again ice of Wisconsinan age. Likewise, ice at the edge of the Barnes Ice Cap in Arctic Canada, also considered by Hooke (1976) to be of Wisconsinan age, is finer-grained (Hooke, 1973). Because of the micro-particle/ice crystal-size relationships in $\mathrm{D}_{72}$ and $\mathrm{D}_{73} \mathrm{~s}$ and now in the Byrd Station core, we suggest the Vostok and Barnes Ice Cap Wisconsin ice also has high micro-particle concentrations. Such high dust concentrations in all five areas, three in the High Arctic and two in the Antarctic, attest to globally high dust levels in the atmosphere during large parts of the Last Ice Age. The widespread occurrence of the high 
dust concentrations at different levels in each ice sheet confirms that in $\mathrm{D}_{72}$ and $\mathrm{D}_{73}$ they are not of bed origin.

There is also a generally high dust level in the lowermost $700 \mathrm{~mm}$ of $\mathrm{D}_{72}$ and $\mathrm{D}_{73}$ (Fig. I) but there are also several dirt pockets in the same section. The pockets bear a very close similarity to the pebble-like clots described by Gow and others (1979). The pockets are spherical or pear-shaped groups of clay-sized particles. They resemble similar features found throughout the stagnant Meighen Ice Cap (Koerner, I968), which, like the Devon Island ice cap, is also frozen to its bed. Because of the similarity between the two sets of dirt inclusions, one of which occurs in a stagnant ice cap, we consider them to be of wind-blown origin, the dirt concentrating into pockets near the surface by melting each summer at a period when the climate was warmer than now.

\section{ICE TEXTURE}

Surprisingly perhaps, we have found no major variations in the strength or position of the single-pole $c$-axis concentration in the basal layers despite other variations in the ice texture.

The bubbles in $\mathrm{D}_{72}$ and $\mathrm{D}_{73}$, which begin by being uniformly distributed, appear to have migrated at depth (e.g. Fig. 3) where the distribution becomes non-uniform. Bubble stretching begins below $150 \mathrm{~m}$ and is most pronounced just above the fine-grained section $\mathrm{B}$. However, section B is twice as bubbly as the ice above or below it (Table I). We do not believe this is a bed effect but rather a sedimentary feature as it also appears in ice of comparable age on the Barnes Ice Cap (Hooke, 1973). It may be due to a completely different type of snow grain accumulating at the surface during the extremely cold period when section B was deposited, so that more air was entrapped at the firn/ice transition depth.

The lowermost section, $\mathrm{D}$, in contrast to $\mathrm{B}$, is characterized by a paucity of bubbles (Table I). One possible explanation for the clearness of the ice formed at the bottom of the ice is that it has undergone melting and refreezing at some stage in its history. The ice could, for example, have formed as superimposed ice when at the surface of the ice cap. This explanation fits our conclusion, based upon the dirt inclusions, of a small Meighen-type ice cap. However, the $\delta$ values of the clear ice differ only marginally from those of the ice above it (Fig. 2). As run-off occurs in the superimposed-ice zone of an ice cap, part of the balance-year accumulation is lost from that zone. Thus $\delta$ values in such ice represent sets of incomplete years compared to complete-year representation of ice formed in the firn zone. $\delta$ values between the two ice types would therefore be expected to differ substantially and this is not the case. A more serious objection than this to the suggestion that the clearness of the ice is due to formation in the superimposed-ice zone is that the section represents a time period of about 20 ooo years (Paterson and others, 1977). This is too long for any point to remain in the climatically narrow zone of superimposed ice formation considering the variability of climate over such a time period. This is especially true when we consider that the superimposed ice zone is further divided into two sections - an upper one of more bubbly ice and a lower one of clearer ice (Koerner, 1970). We have, therefore, two alternatives to consider. First, that the timescale in this layer is grossly incorrect and, secondly, that the ice is not formed in the superimposed ice zone. Originally, Fisher (unpublished [a]), from a comparison of the Devon Island $\delta$ profiles with those from Camp Century, believed the time-scale/depth relationship for $5 \mathrm{~m}$ above the bed was linear. Considering the "missing" layers, this relationship, if correct, had to be fortuitous. If we accept that the ice was formed in the superimposed ice zone of the Devon Island ice cap, then the ice must be younger than even the linear time-scale predicts as the superimposed ice layer must represent a period substantially less than 20 ooo years. The alternative, and to us more agreeable explanation, is that the clear ice is not a sedimentary feature but is of a tectonic origin. The clear ice encompasses both the dirty "small ice-cap", ice in the lowermost $700 \mathrm{~mm}$ and the cleaner ice above it. In addition, the clear ice coincides 
with a zone of finer-grained ice, where, while there is still a reasonable relationship between crystal size and micro-particle concentration $(r=0.6$ significant at the 0.05 level), the finer grain-size (Table I) may also reflect the effect of high shear stress near the bed (cf. the ultrafine-grained) ice in the lowermost ro $\mathrm{m}$ of the Camp Century core (Herron and Langway, 1979)). We have shown that the micro-particle variations are of sedimentary origin, so we might expect the textural variations to be synchronous if they were also of sedimentary origin. While this evidence is by no means conclusive, it suggests the clear texture of the ice in the lowermost $700 \mathrm{~mm}$ of $\mathrm{D}_{72}$ and $\mathrm{D}_{73}$ is more likely to be a tectonic than a sedimentary feature.

\section{IMPLICATIONS}

At present it would appear that the textural and micro-particle concentration variations of the ice in the basal layers, with the possible exception of the texture of the ice for $700 \mathrm{~mm}$ above the bed, are of climatic rather than tectonic origin. This means that in the case of an ice cap frozen to its bed the ice has no erosional effect on the bed. If it did, we would expect to find some of the bed within the ice itself; this is not the case.

Because perturbations in flow in the lower I $3 \mathrm{~m}$ of the Devon Island cores have caused the vertical strain-rate to vary from place to place at the bed of the glacier, ice cores from ice caps other than those of Greenland and Antarctica will most likely have slightly disturbed climatic records beyond 5000 years before present and discontinuous records beyond 10 ooo years before present.

\section{REFERENGES}

Barkov, N. E. 1973. Resul'taty issledovaniya skvazhiny i ledyanogo kerna na stantsii Vostok v 1970-1972 gg. [Results of the investigation of the bore hole and ice core at Vostok Station in 1970-72]. Materialy Glyatsiologicheskikh Issledovaniy. Khronika. Obsuzhdeniya, Vyp. 22, p. 77-81.

Benson, C. S. 1961. Stratigraphic studies in the snow and firn of the Greenland ice sheet. Folia Geographica Danica, Tom. 9, p. 13-37.

Cragin, J. H., and others. [ ${ }^{c}$ I977.] Interhemispheric comparison of changes in the composition of atmospheric precipitation during the late Cenozoic era, by J. H. Cragin, M. M. Herron, C. C. Langway, Jr, and G. [A.] Klouda. (In Dunbar, Maxwell J., ed. Polar oceans. Proceedings of the Polar Oceans Conference held at McGill University, Montreal, May 1974. Sponsored by the Scientific Committee on Oceanic Research (SCOR) and by the Scientific Committee on Antarctic Research (SCAR) of the International Council of Scientific Unions. Calgary, Alberta, Arctic Institute of North America, p. 617-31.)

Dansgaard, W., and others. 1969. One thousand centuries of climatic record from Camp Century on the Greenland ice sheet, by W. Dansgaard, S. J. Johnsen, J. Møller, and C. C. Langway, Jr. Science, Vol. 166, No. 3903, p. $377-8 \mathrm{r}$.

Fisher, D. A. Unpublished[a]. A study of two $\delta\left(\mathrm{O}^{18}\right)$ records from Devon ice cap, Canada, and comparison of them to Camp Century $\delta$ record, Greenland. [Ph.D. thesis, University of Copenhagen, 1976.]

Fisher, D. A. Unpublished[b]. Ice crystals, $\delta\left(\mathrm{O}^{18}\right)$, and dust in Devon Island ice cap cores. [Internal report, Polar Continental Shelf Project, Dept. of Energy, Mines and Resources, Ottawa, 1977.]

Gell, A. W. Unpublished. Ice petrofabrics, Tuktoyaktuk, N.W.T., Canada. [Ph.D. thesis, University of British

Columbia, I973.]
Gow, A. J., and Williamson, T. 1976. Rheological implications of the internal structure and crystal fabrics of the West Antarctic ice sheet as revealed by deep core drilling at Byrd Station. Geological Society of America. Bulletin, Vol. 87, No. 12, p. 1665-77.

Gow, A. J., and others. 1979. On the origin of stratified debris in ice cores from the bottom of the Antarctic ice sheet, by A. J. Gow, S. Epstein, and W. Sheehy. Fournal of Glaciology, Vol. 23, No. 89, p. 185-92.

Hammer, C. U., and others. 1978. Dating of Greenland ice cores by flow models, isotopes, volcanic debris, and continental dust, by C. U. Hammer, H. B. Clausen, W. Dansgaard, N. Gundestrup, S. J. Johnsen, and N. Reeh. Fournal of Glaciology, Vol. 20, No. 82, p. 3-26.

Herron, S. L., formerly Hoar, S. L., and Langway, C. C., jr. 1979. The debris-laden ice at the bottom of the Greenland ice sheet. Fournal of Glaciology, Vol. 23, No. 89, p. 193-207.

Hooke, R. L. r 973 . Structure and flow in the margin of the Barnes Ice Cap, Baffin Island, N.W.T., Canada. Journal of Glaciology, Vol. 12, No. 66, p. 423-38.

Hooke, R. L. 1976. Pleistocene ice at the base of the Barnes Ice Cap, Baffin Island, N.W.T., Canada. Journal of Glaciology, Vol. I 7, No. 75, p. 49-59. 
Hughes, T. J. 1977. Do oxygen isotope data from deep coreholes reveal dike-sill thermal convection in polar ice sheets? [Union Géodésique et Géophysique Internationale. Association Internationale des Sciences Hydrologiques. Commission des Veiges et Glaces.] Symposium. Isotopes et impuretés dans les neiges et glaces. Actes du colloque et Grenoble, août/septembre, 1975 , p. 336-40. (IASH-AISH Publication No. I 18. )

Johnsen, S. J. 1977. Stable isotope homogenization in polar firn and ice. [Union Géodésique et Géophysique Internationale. Association Internationale des Sciences Hydrologiques. Commission des Neiges et Glaces.] Symposium. Isotopes et impuretés dans les neiges et glaces. Actes du colloque de Grenoble, août/septembre, 1975, p. 210-19. (IAHS-AISH Publication No. 118. .)

Koerner, R. M. 1968. Fabric analysis of a core from the Meighen ice cap, Northwest Territories, Canada. Journal of Glaciology, Vol. 7, No. 51, p. 42 I-30.

Koerner, R. M. 1970. Some observations on superimposition of ice on the Devon Island ice cap, N.W.T., Canada. Geografiska Annaler, Vol. 52A, No. 1, p. 57-67.

Kotlyakov, V. M. I961. Skhema intensivnosti pitaniya lednikovogo pokrova Antarktidy [Outline of the nourishment intensity of the Antarctic ice sheet]. Informatsionnyy Byulleten' Sovetskoy Antarkticheskoy Ekspeditsii, No. 25, p. 19-22.

Lawson, D. E. 1979. Characteristics and origins of the debris and ice, Matanuska Glacier, Alaska. Fournal of Glaciology, Vol. 23, No. 89, p. 437-38.

Paterson, W. S. B. I977. Secondary and tertiary creep of glacier ice as measured by borehole closure rates. Reviews of Geophysics and Space Physics, Vol. I 5 , No. 1, p. 47-55.

Paterson, W. S. B., and Koerner, R. M. 1974. Radio echo sounding on four ice caps in Arctic Canada. Arctic, Vol. 27, No. 3, p. 225-33.

Paterson, W. S. B., and others. 1977. An oxygen-isotope climatic record from the Devon Island ice cap, Arctic Canada, [by] W. S. B. Paterson, and R. M. Koerner, D. Fisher, S. J. Johnsen, H. B. Clausen and W. Dansgaard, P. Bucher and H. Oeschger. Nature, Vol. 266, No. 5602, p. 508-i I.

Ragone, S. E., and others. I972. Cationic analysis of the Camp Century, Greenland, ice core, [by] S. E. Ragone, R. V. Finelli, S. Leung, and C. Wolf. U.S. Cold Regions Research and Engineering Laboratory. Special Report 179.

Thompson, L. G., and others. I975. Climatological implications of microparticle concentrations in the ice core from "Byrd" Station, western Antarctica, by L. G. Thompson, W. L. Hamilton, and C. [B. B.] Bull. Fournal of Glaciology, Vol. 14, No. 72, p. 433-44.

\section{DISCUSSION}

S. L. Herron: It might be possible that grain-size is useful as a climatic indicator. The crystal-size change in Wisconsin-aged ice you observe in the Devon Island core and which is apparent in the Byrd Station core is also present in Wisconsin ice from Camp Century.

R. M. Koerner: The effect of temperature on grain-size is small compared to the effect of micro-particles when present above a certain threshold concentration. In addition, we have fine-grained ice in isotopically very warm ice close to the bed. Again, this near-basal ice has high micro-particle concentrations.

A. J. Gow: In reply to your statement that glaciologists have inferred strong shearing in ice on the basis of the fine-grained nature of the ice, I should like to say that this is not strictly correct. The best evidence for shearing is the $c$-axis fabric, especially single-pole fabrics of the kind observed in the zone at $\mathrm{I} 200-1800 \mathrm{~m}$ depth at Byrd Station. The ice is also finegrained, as is frequently observed in ice exhibiting single-pole fabrics. Fineness of crystal size goes along with the idea that strong shearing may be accompanied by granulation of the ice crystals.

Koerner: I refer you to the text of the paper I have just presented where we note that no statistically significant differences between the single-pole fabrics of the shearing zone and the single-pole fabrics of the enclosing ice in the Byrd Station core have been demonstrated. The only significant difference published to date lies in the crystal size which can be associated with differences in the dirt content and distribution.

J. Clough: Do these basal layers of fine-grained ice also contain particles? Are there any fine-grained zones that do not contain particles? 
Gow: Regarding the Byrd Station cores, ultra-fine-grained ice always contained particles. These ultra-fine-grained ice layers are also composed of crystals with vertical or near-vertical $c$-axes, indicative of strong shearing.

R. P. Goldthwait: I take it from the Dansgaard isotopic curves that there is evidence for two long Wisconsin interstadial periods.

KOERnER: Yes.

J. Weertman: You suggest that the discontinuity in the oxygen-isotope curve may be evidence of shearing. The centre of an ice cap is the least likely region for shearing to take place. Can you present a cross-section picture of the ice cap showing this shearing motion? Since, as you mention, S. Johnsen's diffusion calculations indicate that the sharpness of the isotopecurve discontinuity requires it to be less than I ooo years old, any shearing must have taken place when the centre of the ice cap had essentially its present position.

KOERNER: When we consider that some of the steep isotope gradients are associated with discrete changes in the crystal size, then the isotope gradient becomes even steeper and its age considerably less than $\mathrm{I}$ ooo years. Our core is not right at the crest but about goo m downslope. Recent work by C. Raymond (personal communication) also indicates the flow line is from further up the ice cap and may be more than a couple of kilometres in length. 